\title{
ANALISIS BUTIR SOAL DAN KEMAMPUAN SISWA DALAM MENJAWAB SOAL UJIAN NASIONAL PADA MATA PELAJARAN EKONOMI
}

\author{
${ }^{1}$ Dini Riani, ${ }^{2}$ Saiful Almujab, ${ }^{3}$ Amelia Dina, ${ }^{3}$ Fitriani, ${ }^{4}$ Riko Budiarto \\ $1,2,3,4$ Universitas pasundan \\ email: ${ }^{1}$ diniriani@unpas.ac.id
}

\begin{abstract}
ABSTRAK
Penelitian ini bertujuan untuk menganalisis sejauh mana butir-butir soal dalam soal Ujian Nasional mata pelajaran ekonomi tahun ajaran 2016/2017 mampu mengarahkan siswa-siswa di SMA Pasundan se-Bandung pada pengembangan berpikir tingkat tinggi. Analisis tersebut dilakukan dengan melihat karakteristik soal ujian nasional kemudian dilakukan pengkatagorisasian berdasarkan ranah kognitif Bloom. Sedangkan untuk analisis butir soal, peneliti melakukan analisis jawaban siswa untuk menentukan bagaiman tingkat kesukaran, daya pembeda dan efektifitas pengecoh pada soal UN. Dalam penelitian ini, peneliti juga melakukan analisis terhadap kemampuan siswa dalam menjawab soal-soal UN dengan menentukan jenis soal mana saja yang dianggap sulit berdasarkan jawaban yang dihasilkan. Metode penelitian yang digunakan adalah deskriptif kuantitatif, sedangakan data diolah mengunakan ANATES V.4. untuk kemudian ditarik kesimpulan. Hasil penelitian diharapkan dapat memberikan kontribusi bagi manajemen sekolah dan guru-guru ekonomi dalam mengembangkan materi pembelajaran yang mengarahkan pada kecakapan siswa dalam menjawab soal-soal yang terdapat di Ujian Nasional. Hasil penelitian menunjukan bahwa masih terdapat soal-soal dalam ujian nasonal khususnya pada mata pelajaran ekonomi yang perlu dilakukan evaluasi ulang karena memiliki kategori soal yang buruk.
\end{abstract}

Kata kunci: Analisis butir, Soal Ujian Nasional.

\begin{abstract}
This study aims to analyze the extent to which the items in the National Examination subjects for the 2016/2017 academic year are able to direct students in Pasundan High School in Bandung to develop high-level thinking. The analysis was carried out by looking at the characteristics of the national exam questions then categorizing based on Bloom's cognitive domain. As for the analysis of the items, the researcher analyzes the students' answers to determine how difficult, differentiating, and the effectiveness of the deception in the UN questions. In this study, researchers also conducted an analysis of students' ability to answer UN questions by determining which types of questions were considered difficult based on the answers generated. The research method used is quantitative descriptive, while the data is processed using ANATES V.4. to then draw conclusions. The results of the study are expected to contribute to school management and economic teachers in developing learning materials that lead to students' skills in answering questions contained in the National Examination. The results showed that there were still questions in national exams, especially in economic subjects that needed to be re-evaluated because they had poor question categories.
\end{abstract}

Keywords: Item analysis, National Examination. 


\section{PENDAHULUAN}

Pendidikan merupakan elemen yang sangat penting untuk menciptakan sumber daya yang berkualitas, cerdas, damai, terbuka, demokratis, dan mampu bersaing serta dapat meningkatkan kesejahteraan semua warga Indonesia. Perkembangan dan perubahan yang terjadi dalam kehidupan di Indonesia tidak terlepas dari pengaruh global, perkembangan ilmu pengetahuan dan tekhnologi, serta seni dan budaya. Melalui pendidikan diharapkan Negara dapat maju dan berkembang sesuai dengan kemajuan dan tuntutan zaman. Disamping itu pendidikan juga dituntut maju dan berkembang sejalan dengan perkembangan ilmu pengetahuan dan tekhnologi. Untuk itu, peningkatan kualitas pendidikan di Indonesia perlu terus dilakukan untuk menciptakan dunia pendidikan yang adaptif terhadap perubahan zaman. Dalam rangka meningkatkan kualitas pendidikan dibutuhkan komponen-komponen pendukung dalam pendidikan, evaluasi memiliki peran penting untuk mendukung perkembangan pendidikan.

Evaluasi di definisikan beragam oleh para ahli, namun pada intinya evaluasi pendidikan berkaitan dengan penilaian dalam pendidikan. Evaluasi yang di maksud adalah evaluasi terkait dengan keberhasilan peserta didik setelah mengikut jenjang belajar tertentu dalam kurun waktu tertentu (Setiani \& Donni, 2015). Selain itu, Purwanto (2013:1) mengatakan "Evaluasi adalah pengambilan keputusan berdasarkan hasil pengukuran dan standar kriteria untuk mengetahui apakah penyelenggaraan program dapat mencapai tujuan secara efektif dan efisien". Untuk itum, evaluasi merupakan proses menentukan sampai berapa jauh kemampuan yang dapat dicapai siswa dalam proses pembelajaran.

Pada umumnya evaluasi terhadap suatu proses pembelajaran dilakukan untuk mengetahui sejauh mana pelaksanaan pembelajaran tersebut telah mencapai tujuan yang telah ditetapkan. Dengan adanya evaluasi seorang guru akan mengetahui gambaran yang jelas tentang daya serap peserta didik yang dihadapinya, kedudukan peserta didik dalam kelompok, keunggulan dan kelemahan peserta didik dibandingkan dengan yang lainnya, ketepatan atau keefektifan metode yang digunakan, Tingkat Kesukaran materi pelajaran, efektifitas dan efisiensi proses pembelajaran yang dilaksanakan. Informasi yang diperoleh dari kegiatan evaluasi tersebut akan bermanfaat sebagai bahan umpan balik dalam proses pembelajaran. Umpan balik ini nantinya akan dijadikan sebagai evaluasi pada proses pembelajaran selanjutnya.

Ujian nasional merupakan salah satu instrumen evaluasi dalam pendidikan yang sudah terstandarisasi dan bertujuan untuk mengukur hasil belajar siswa yang dilaksanakan pada akhir pengajaran suatu program pendidikan. Ujian Nasional adalah kegiatan penilaian hasil belajar peserta didik yang telah menyelesaikan jenjang pendidikan pada jalur sekolah/madrasah yang diselenggarakan secara nasional. Berdasarkan Permendikbud No. 66 tahun 2013 tentang Standar Penilaian Pendidikan, Ujian Nasional yang selanjutnya disebut UN merupakan kegiatan pengukuran kompetensi tertentu yang dicapai peserta didik dalam rangka menilai pencapaian Standar Nasional Pendidikan, yang dilaksanakan secara nasional (Widoyoko, 2016:45). Hasil ujian nasional tersebut digunakan untuk mengambil suatu keputusan dalam program pendidikan selanjutnya. Penilaian hasil belajar, menurut Permendikbud Nomor 4 Tahun 2018 tentang Penilaian Hasil Belajar oleh Satuan Pendidikan dan Penilaian Hasil Belajar oleh Pemerintah, terdiri atas US dan/atau USBN (Ujian Sekolah; Ujian Sekolah Berstandar Nasional) dan UN (Ujian Nasional). Satuan Pendidikan melakukan penilaian hasil belajar melalui US dan/atau USBN. Sedangkan pemerintah melalui Ujian Nasional (UN). Dimana ketentuan lebih lanjut terkait keduanya, diatur lebih lanjut dengan keputusan yang ditetapkan oleh Badan Standar Nasional Pendidikan (BSNP). Untuk itu, walupun sejak tahun 2015 hasil UN tidak dijadikan standar dalam menentukan kelulusan peserta didik, namun hasil siswa dalam menjawab soal UN dapat dijadikan tolak ukur sejauh mana siswa mampu memahami materi-materi ajar yang terstandarisasi secara nasional.

Kemampuan siswa dalam memahami pembelajaran merupakan kecakapan seorang peserta didik, yang dimiliki dari hasil apa yang telah dipelajari yang dapat ditunjukkan atau dilihat melalui hasil belajarnya (Syah, 2014:150). Ada tiga ranah (aspek) yang terkait dengan kemampuan siswa dalam belajar, yaitu ranah kognitif (pengetahuan), ranah afektif (sikap), 
dan ranah psikomotorik (keterampilan). Contoh ranah kognitif adalah kemampuan siswa dalam menganalisis suatu masalah berdasarkan pemahaman yang dimilikinya. Contoh ranah afektif adalah siswa mampu menentukan sikap untuk menerima atau menolak suatu objek. Contoh ranah psikomotorik adalah siswa mampu berekspresi dengan baik.

Untuk itu, dalam hal ini penting dilakukan analisis butir tes sebagai kajian tentang isi butir-butir soal dalam instrumen tes agar diperoleh seperangkat butir tes yang memiliki kualitas yang memadai. Analisis butir tes bertujuan untuk mengidentifikasi butir-butir soal dalam instrumen tes yang baik, kurang baik dan tidak baik. Ada beberapa alasan mengapa diperlukan analisis butir tes menurut Asmawi Nainul dan Noehi Nasution, dalam Widoyoko (2016:173). Alasan tersebut antara lain; 1) untuk dapat mengetahui kekuatan dan kelemahan butir tes;2) untuk menyediakan informasi tentang spesifikasi butir tes secara lengkap; 3) untuk dapat segera dapat diketahui masalah yang terkandung dalam butir soal; serta 4) untuk dijadikan alat guna menilai butir tes yang akan disimpan dalam bank soal.

Biasanya hal-hal yang dianalisis dalam spesifikasi butir tes adalah hal-hal yang berkaitan dengan materi tes, konstruksi soal dan kaitannya dengan bahan serta budaya di masyarakat tempat butir tes itu disusun. Dalam bidang pengukuran, dikenal beberapa karakteristik butir soal. Untuk tes hasil belajar umumnya dipertimbangkan 3 (tiga) karakteristik butir soal, yaitu: tingkat kesulitan (difficulty index), daya beda (discriminating power), dan efektivitas pengecoh (distractor effectivity).

Tingkat kesulitan (difficulty index, difficulty level) butir tes adalah proporsi peserta tes menjawab dengan benar terhadap suatu butir tes. Sedangkan angka yang menunjukkan sulit atau mudahnya suatu butir tes dinamakan dengan indeks kesulitan yang dilambangkan dengan $\mathrm{p}$ (proportion correct). Makin besar nilai $\mathrm{p}$ berarti makin besar proporsi peserta tes yang menjawab benar terhadap suatu butir tes, makin rendah tingkat kesulitan butir tes itu, yang berarti butir tes itu makin mudah. Sebaliknya semakin kecil nilai $p$ berarti semakin kecil proporsi peserta tes menjawab dengan benar suatu butir tes, makin tinggi tingkat kesulitan butir tes itu, yang berarti butir tes itu makin sulit. Sementara itu, Menurut Asmawi Zainul dan Noehi Nasution dalam Eko Putro Wdoyoko (2016, hlm. 180) "Daya beda (discriminating power) butir tes adalah indeks yang menunjukkan tingkat kemampuan butir tes membedakan antara peserta tes yang pandai (kelompok atas) dengan peserta tes yang kurang pandai (kelompok bawah) di antara peserta tes." Sedangkan Efektivitas Pengecoh (distractor effectivity) menurut B. Uno (2013) merupakan analisis pola jawaban yang dilakukan dengan menghiyung peserta tes yang memilih tiap alternative jawaban pada masing-masing item.

\section{METODE PENELITIAN}

Penelitian ini bertujuan untuk menganalisis butir soal ujian nasional dan kemampuan siswa dalam menjawabnya di SMA Pasundan 1 Bandung, dan SMA Pasundan 2 Bandung. Sugiyono (Sugiyono, 2014:3) menyatakan bahwa metode penelitian adalah cara ilmiah dalam mendapatkan data dengan tujuan dan kegunaan tertentu. Jadi, metode penelitian dapat digunakan untuk mengukur analisis butir soal ujian nasional.

Metode penelitian yang digunakan dalam penelitian ini ialah metode penelitian deskriptif kuantitatif. Penelitian ini dimaksudkan untuk mencari informasi dan data yang dapat digunakan untuk mendeskripsikan kualitas tes. Pendekatan yang digunakan dalam penelitian ini adalah pendekatan kuantitatif karena data yang diperoleh dalam bentuk angka-angka dan dianalisis untuk kemudian ditarik kesimpulan dengan menggunakan program Anates Versi 4.

Populasi dari penelitian ini adalah siswa kelas XI di SMA Pasundan se-Bandung berjumlah berjumlah 436 siswa, kemudian peneliti mengambil sampel berjumlah 267 siswa. Sedangkan data penelitian diperoleh dengan menggunakan analisis dokumen yang meliputi soal Ujian Nasional mata pelajaran ekonomi tahun pelajaran 2016/2017, kunci jawaban, dan lembar jawab siswa. Untuk itu analisis data dalam penelitian ini menggunakan analisis butir tes dari jawaban siswa terhadap soal-soal ujian nasional matapelajaran ekonomi. Analisis butir tes adalah pengkajian tentang isi butir-butir soal dalam instrumen tes agar diperoleh seperangkat butir tes yang memiliki kualitas yang memadai. Analisis butir tes bertujuan untuk mengidentifikasi butir-butir soal dalam instrumen tes yang baik, kurang baik dan tidak baik. 
Dalam pengukurannya, peneliti menggunakan 3 (tiga) karakteristik butir soal, yaitu: tingkat kesulitan (difficulty index), daya beda (discriminating power), dan efektivitas pengecoh (distractor effectivity).

\section{Tingkat Kesulitan}

Perhitungan Tingkat Kesukaran merupakan perhitungan proporsi antara siswa yang dapat menjawab benar suatu butir soal dengan jumlah seluruh peserta tes. Bilangan yang menunjukkan sukar mudahnya suatu soal disebut indeks kesukaran. Rumus yang digunakan untuk menghitung indeks kesukaran butir soal untuk bentuk soal objektif sebagai berikut:

$$
P=\frac{B}{J S}
$$

Keterangan:

$\mathrm{P} \quad=$ Indeks kesukaran

$\mathrm{B}$ = Banyaknya siswa yang menjawab soal dengan benar

JS = Jumlah seluruh siswa peserta tes

(Arikunto, 2016:223)

Tabel 1

Klasifikasi Tingkat Kesukaran

\begin{tabular}{cc}
$\begin{array}{c}\text { Indeks } \\
\text { Kesukaran }\end{array}$ & $\begin{array}{c}\text { Kategori Tingkat } \\
\text { Kesukaran }\end{array}$ \\
\hline $0 \quad \square 0,30$ & Sukar \\
$0,31-0,70$ & Sedang \\
$0,71-1,00$ & Mudah \\
\hline (Sudjana, 2014) &
\end{tabular}

\section{Daya Beda}

(Sudjana, 2014)

Adapun rumus untuk mencari indeks daya beda adalah sebagai berikut:

Keterangan:

$$
D \frac{B_{A}}{J_{A}}-\frac{B_{B}}{J_{B}}=P A-P B
$$

$\mathrm{J}=$ Jumlah peserta tes

$\mathrm{JA}=$ Banyaknya peserta kelompok atas

$\mathrm{JB}=$ Banyaknya peserta kelompok bawah

$\mathrm{BA}$ = Banyaknya peserta kelompok atas yang menjawab soal dengan benar

$\mathrm{BB}=$ Banyaknya peserta kelompok bawah yang menjawab soal dengan benar

$\mathrm{PA}=$ Proporsi peserta kelompok atas yang menjawab benar

PB $=$ Proporsi peserta kelompok bawah yang menjawab benar

(Arikunto, 2016: 228-229)

Penentuan Daya Pembeda dapat menggunakan klasifikasi sebagai berikut:

$\mathrm{D}=0,00-0,20=$ jelek (poor)

$\mathrm{D}=0,21-0,40=$ cukup (satisfactory)

$\mathrm{D}=0,41-0,70=$ baik (good)

$\mathrm{D}=0,71-1,00=$ baik sekali (excellent)

$\mathrm{D}=$ negatif, semuanya tidak baik. Jadi, sebaiknya dibuang.

(Arikunto, 2016:232) 


\section{Efektivitas Pengecoh}

Kriteria pengecoh yang baik adalah apabila pengecoh tersebut dipilih oleh paling sedikit $5 \%$ dari peserta tes. Efektivitas pengecoh dapat diukur menggunakan rumus:

$$
I P=\frac{P}{(N-B) /(n-1)} \times 100 \%
$$

Keterangan :

$\mathrm{IP}=$ indeks pengecoh

$\mathrm{P}=$ Jumlah peserta didik yang memilih pengecoh

$\mathrm{N}=$ Jumlah peserta didik yang mengikuti tes

$\mathrm{B}=$ Jumlah peserta didik yang menjawab benar pada setiap soal

$\mathrm{n}=$ Jumlah alternatif jawaban (opsi)

$1=$ Bilangan tetap

\section{HASIL PENELITIAN DAN PEMBAHASAN}

Berdasarkan hasil yang diperoleh dari analisis soal Ujian Nasional mata pelajaran ekonomi tahun ajaran 2016/2017 di SMA Pasundan se-Bandung adalah sebagai berikut:

\section{Kemampuan Siswa Dalam Menjawab Soal Ujian Nasional}

Berdasarkan analisis lembar jawaban siswa dengan soal sebanyak 28 soal uji, diperoleh data sebagai berikut:

Tabel 2 Frekuensi Kemampuan Siswa Menjawab dengan Benar

\begin{tabular}{ccc}
\hline $\begin{array}{c}\text { Range Jumlah } \\
\text { Benar }\end{array}$ & $\begin{array}{c}\text { Frekuensi } \\
\text { Siswa }\end{array}$ & Persentase \\
\hline $1-7$ & 43 & $16 \%$ \\
$8-14$ & 139 & $52 \%$ \\
$15-21$ & 73 & $27 \%$ \\
$22-28$ & 12 & $4 \%$ \\
\hline Jumlah Siswa & 267 & $100 \%$ \\
\hline
\end{tabular}

Berdasarkan data tersebut hanya 85 (32\%) siswa yang mampu menjawab lebih dari setengah soal uji dengan benar, sedangakan sebanyak 182 (68\%) siswa belum mampu menjawab setengah soal uji dengan benar. Data tersebut menunjukan kemampuan siswa dalam menjawab soal ujian nasional masih tergolong rendah. Peneliti menduga rendahnya kemampuan siswa dikarenakan siswa belum mampu mengkontruksi materi-materi ajar yang telah diberikan ke dalam proses kognitif yang lebih tinggi (High Order Tinking). Hal tersebut terlihat dari hasil lembar jawab siswa, dimana siswa baru mampu menjawab soal-soal yang memiliki karakteristik recall atau mengingat kembali. Hal tersebut tentu bukan merupakan tujuan utama pembelajaran dimana belajar merupakan pembentukan makna (meaning) dengan cara membangun atau mengkonstruksi hubungan antara pengetahuan yang telah dimiliki dengan pengetahuan yang baru (Waseso, 2018).

\section{2. klasifikasi soal ujian nasional terhadap taksonomi bloom}

Berdasarkan analisis terhadap soal ujian nasional mata pelajaran ekonomi tahun ajaran 2016/2017 yang ditinjau dari dimensi kognitif dan pengetahuan taksonomi bloom. Dimensi kognitif dibagi kedalam berbagai tingkatan yaitu $\mathrm{C} 1$ remembering (mengingat), C2 understanding (memahami), C3 applying (menerapkan), C4 analyzing (menganalisis), C5 evaluating (menilai), dan C6 creating (mencipta). Sedangkan dimensi pengetahuan dibagi ke dalam 4 tingkatan yaitu factual (faktual), conceptual (konseptual), Procedural (Prosedur) dan metacognitive (metakognitif). Dari hasil analisis didapat data sebagai berikut: 
Tabel 3 Karakteristik Item soal UN

\begin{tabular}{llcccccc}
\hline No & $\begin{array}{l}\text { The Cognitive } \\
\text { Process }\end{array}$ & Factual & $\begin{array}{c}\text { The Knowledge Dimension } \\
\text { Concep- } \\
\text { tual }\end{array}$ & $\begin{array}{c}\text { Proce- } \\
\text { dural }\end{array}$ & $\begin{array}{c}\text { Meta- } \\
\text { cognitive }\end{array}$ & Total & $\%$ \\
\hline 1 & Remembering & - & 2 & - & - & 2 & $7,1 \%$ \\
2 & Understanding & 2 & 3 & - & - & 5 & $17,9 \%$ \\
3 & Applying & - & 9 & 3 & - & 12 & $42,9 \%$ \\
4 & Analyzing & 1 & 6 & 1 & - & 8 & $28,6 \%$ \\
5 & Evaluating & - & 1 & - & - & 1 & $3,6 \%$ \\
6 & Creating & - & - & - & - & - & - \\
\hline \multicolumn{7}{c}{ Total } &
\end{tabular}

Dari hasil analisis, maka didapatlah bahwa soal dalam ranah kognitif dari 28 soal yang dianalisis ialah $\mathrm{C} 1$ (recognition) sejumlah 0 butitr soal $(0 \%), \mathrm{C} 2$ (recognition) sejumlah 2 butir (7,14\%), C3 (application) sejumlah 8 butir soal (28,57\%), C4 (analysis) sejumlah 17 butir soal (60.71\%), C5 (synthesis) sejumlah 1 (3,57\%), dan C6 ( evaluation) sejumlah 0 butir soal $(0 \%)$. Hasil penelitian menunjukan bahwa keterampilan berpikir tingkat tinggi pada soal UN mata pelajaran ekonomi masih berfokuspada soal menganalisis. Padahal menurut Lyn, Ramos, Dolipas, \& Villamor (2019) keterampilan berpikir tingkat tinggi memiliki korelasi tinggi dengan kinerja akademik, meliputi: kemampuan untuk melakukan analisis, perbandingan, kesimpulan, dan evaluasi. Arends (2001) menyatakan bahwa pemikiran tingkat tinggi memiliki sifat: tidak algoritmik, tindakan tidak dapat sepenuhnya ditentukan sebelumnya; kompleks, sehingga tidak bisa dilihat dari satu perspektif saja; multi-solusi, tidak hanya memiliki solusi, tetapi memiliki banyak alternatif dengan kelebihan dan kekurangan masing-masing; membutuhkan pertimbangan dan interpretasi; melibatkan banyak kriteria yang terkadang saling bertentangan; sering tidak pasti; menuntut pengaturan diri dalam proses berpikir; menciptakan makna baru yang lebih tinggi; dan menggambarkan kerja keras dan proses mental yang terjadi dengan sungguh-sungguh. Hasil tersebut secara tersirat menunjukan bahwa secara umum pembelajaran di Indonesia saat ini belum mengarah pada pembentukan kecakapan berpikir tingkat tinggi dan literasi ilmiah terutama pada proses berpikir Evaluatif (C5) dan Mencipta (C6).

\section{Distribusi Tingkat Kesukaran, Daya Pembeda Dan Efektivitas Pengecoh Soal Ujian Nasional.}

a) Distribusi Soal Ujian Nasional Berdasarkan Indeks Tingkat Kesukaran

Dari hasil analisis data penelitian, distribusi soal ujian nasional berdasarkan indeks tingkat kesukaran di SMA Pasundan se-Bandung didapatkan hasil sebagai berikut:

Tabel 4 Distribusi Soal Ujian Nasionnal Berdasarkan Indeks Tingkat Kesukaran

\begin{tabular}{|c|c|c|c|c|}
\hline No. & Tingkat Kesukaran & Butir Soal & Jumlah & $\begin{array}{l}\text { Persentas } \\
\text { e }\end{array}$ \\
\hline 1. & $0,71-1,00$ (mudah) & $1,2,9,13,23$ & 5 & $17,85 \%$ \\
\hline 2. & $\begin{array}{l}0,31- \\
\text { (sedang) }\end{array}$ & $\begin{array}{l}3,4,5,7,10,11,15,16,19,21,22 \\
25,27,28\end{array}$ & 14 & $50 \%$ \\
\hline 3. & $0,00-0,30$ (sukar) & $6,8,12,14,17,18,20,24,26$ & 9 & $32,14 \%$ \\
\hline \multicolumn{3}{|r|}{ Total } & 28 & 100 \\
\hline
\end{tabular}

Berdasarkan hasil analisis diketahui bahwa butir soal ujian nasional di SMA Pasundan se-Bandung yang tergolong sukar berjumlah 9 butir $(32,14 \%)$ yaitu butir soal nomor $6,8,12,14,17,18,20,24$ dan 26 . Soal dalam kategori sedang berjumlah 14 soal (50\%) yaitu butir soal nomor $3,4,5,7,10,11,15,16,19,21,22,25,27$ dan 28 . Soal dalam kategori mudah berjumlah 5 soal (17,85\%) yaitu soal nomor 1, 2, 9, 13, 2 dan 3.

Hasil anlisis kesukaran butir soal menunjukan bahwa masih terdapat $50 \%$ soal dalam kategori sukar dan mudah, soal soal dengan jenis ini perlu dievaluasi ulang keberadaannya karena menurut Daryanto (2010:179), soal yang baik adalah soal yang tidak terlalu mudah 
atau tidak terlalu sukar. Soal yang terlalu mudah tidak merangsang siswa untuk mempertinggi usaha memecahkannya. Sebaliknya soal yang terlalu sukar akan menyebabkan siswa menjadi putus asa dan tidak mempunyai semangat untuk mencoba lagi karena di luar jangkauannya. Tingkat kesukaran soal adalah angka yang menunjukkan bahwa apakah soal yang diujikan termasuk mudah, sedang atau sukar (Yani, Asri, \& Burhan, 2014). Mengacu kepada pendapat tersebut terdapat 14 soal dalam soal Ujian Nasional yang berada dalam kategori cukup sehingga soal-soal yang masuk dalam kategori tersebut perlu dipertahankan.

Salah satu contoh soal dengan tingkat kesukaran kategori sukar adalah seperti dalam soal nomor 6: "Diketahui fungsi permintaan $Q d=3 P-8$. Pada saat harga $R p .20,00$, barang yakan akan ditawarkan 100 unit .....". Soal nomor 6 merupakan soal ujian nasional dalam kategori sukar karena siswa harus sangat memahami materi yang diajarakan dalam proses pembelajaran serta menganalisisnya untuk memilih jawaban yang tepat dari beberapa jawaban di pilihan jawaban yang disediakan. Soal yang terlalu sukar akan menyebabkan siswa menjadi putus asa dan tidak mempunyai semangat untuk mencoba lagi karena diluar jangkauannya. Sedangkan contoh soal yang mudah pada SMA Pasundan 7 dan SMA Pasundan 8 Bandung ada pada soal nomor 1 "Zacky merupakan mahasiswa tingkat akhir yang memiliki kebutuhan sebagai berikut (1) printer seharga Rp750.000,00 ....... Soal tersebut merupakan soal yang mudah untuk dijawab siswa yang telah mengikuti proses pembelajaran karena dari segi materi soal tersebut merupakan soal dengan menggunakan ingatan untuk menjawabnya serta dari segi bahasa juga menggunakan bahasa yang mudah dipahami untuk mencari jawabannya. Soal yang terlalu mudah tidak merangsang siswa untuk mempertinggi usaha memecahkannya. Sedangkan contoh soal yang tingkat kesukarannya sedang seperti pada soal nomor 3 "Bapak Taufik berencana akan membuka usaha laundry di daerah tempat tinggalnya ...." karena dalam proses pencarian jawaban dalam pilihan jawaban yang disediakan tidak mudah dan tidak sukar dalam menjawabnya. Soal yang baik adalah soal yang tidak terlalu sukar dan tidak terlalu mudah.

b) Distribusi Soal ujian nasional terhadap Indeks Daya Pembeda

Dari hasil analisis data penelitian, distribusi soal ujian nasional terhadap indeks daya pembeda di SMA Pasundan se-Bandung didapatkan hasil sebagai berikut:

Tabel 5 Distribusi Soal ujian nasional terhadap Indeks Daya Pembeda

\begin{tabular}{ccccc}
\hline No & Daya Pembeda & Butir Soal & Jumlah & Presentase (\%) \\
\hline 1 & $0,71-1,00$ (Baik sekali) & 2 & 1 & 3,57 \\
2 & $0,41-0,70$ (Baik) & $3,8,9,10,12,13,15,16$, & 9 & 32,14 \\
3 & $0,21-0,40$ (Cukup) & $4,5,6,11,14,20,21,23$, & & \\
& $0,00-0,20$ (Jelek) & $1,7,17,19,24$ & 5 & 39,29 \\
4 & Negatif (Tidak Baik) & 18,26 & 2 & 17,86 \\
5 & & 28 & 100 \\
\hline \multicolumn{2}{c}{ Total } &
\end{tabular}

Berdasarkan hasil analisis diketahui bahwa butir soal ujian nasional di SMA Pasundan se-Bandung yang tergolong negatif (tidak baik) berjumlah 2 butir $(7,4 \%)$ yaitu butir soal nomor 1 dan 26 . Soal dalam kategori jelek berjumlah 5 soal $(17,86 \%)$ yaitu nomor $1,7,17,19$ dan nomor 24 . Soal dalam kategori cukup berjumlah 11 soal $(39,29 \%)$ yaitu nomor 4, 5, 6, 11, 14, 0, 21, 23, 25 dan 28. Soal dalam kategori baik berjumah 9 soal $(32,14 \%)$ yaitu nomor $3,8,9,10,12,13,15,16$ dan 27 . Soal dalam kategori baik sekali berjumlah 1 soal $(3,57 \%)$ yaitu soal nomor 2 .

Dari hasil perhitungan daya pembeda soal menunjukan bahwa masih terdapat beberapa soal UN mata pelajaran ekonomi yang masih berada dalam kategori jelek bahkan tidak baik. Hasil ini dapat dijadikan bahan evaluasi bagi sekolah ataupun pembuat soal bahwa soal-soal dalam kategori jelek dan jelek sekali tidak mampu dijadikan alat untuk membedakan peserta didik yang sudah menguasai kompetensi dengan peserta didik yang 
belum menguasai kompetensi. Untuk itu, jenis-jenis soal dalam kategori daya pembeda negatif atau jelek sekali lebih baik dibuang atau tidak digunakan kembali (Rahayu \& Djazari, 2016). Salah satu contoh soal dengan daya pembeda jelek seperti dalam soal nomor 24 dengan soal sebagai berikut: "Pada saat akan mendirikan usaha, pemilihan bentuk badan usaha perlu mempertimbangkan kebaikan dan kelemahan sebagai berikut...." karena tidak dapat melaksanakan fungsinya yaitu soal yang membedakan siswa yang berkemampuan tinggi dengan siswa yang berkemampuan rendah setelah mengikuti proses pembelajaran. Siswa yang berkemampuan rendah dapat menjawab soal tersebut dengan benar. Selain itu pemilihan bahasa yang singkat dan sangat jelas terkesan mudah untuk dijawab.

c) Distribusi Soal Ujian Nasional Berdasarkan Indeks Efektivitas Pengecoh

Dari hasil analisis data penelitian, distribusi soal ujian nasional berdasarkan indeks tingkat kesukaran di SMA Pasundan se-Bandung didapatkan hasil sebagai berikut:

Tabel 6 Distribusi Soal Ujian Nasional Berdasarkan Indeks Efektivitas Pengecoh

\begin{tabular}{lllcc}
\hline No. & Efektivitas Pengecoh & Butir Soal & Jumlah & Persentase \\
\hline 1. & Sangat Baik & $14,15,16,18,24,25,26,27$ & 8 & $28,57 \%$ \\
2. & Baik & $4,5,6,7,8,12,19,20,21,22$ & 10 & $35,71 \%$ \\
3. & Cukup & $2,3,10,17,28$ & 5 & $17,85 \%$ \\
4. & Kurang Baik & 11,23 & 2 & $7,14 \%$ \\
5. & Tidak Baik & $1,9,13$ & 3 & $10,71 \%$ \\
\hline & & Total & 28 & 100 \\
\hline
\end{tabular}

Berdasarkan hasil analisis diketahui bahwa butir soal ujian nasional yang diujikan di SMA Pasundan 8 Bandung efektivitas pengecohnya di SMA sangat baik berjumlah 8 soal $(28,57 \%)$ yaitu nomor $14,15,16,18,24,25,26$ dan 27 . Soal dalam kategori baik berjumlah 10 soal $(35,71 \%)$ yaitu nomor $4,5,6,7,8,12,19,20,21$ dan 22 . Soal dalam kategori cukup berjumlah 5 soal $(17,85 \%)$ yaitu nomor $2,3,10,17$ dan 28 .. Sola dalam kategori kurang baik berjumlah 2 soal $(7,14 \%)$ yaitu nomor 11 dan 23 . Sedangkan soal dalam kategori tidak baik berjumlah 3 soal (10,71\%) yaitu 1, 9 dan 13 .

Sebuah pengecoh dikatakan telah dapat menjalankan fungsinya dengan baik apabila pengecoh tersebut mempunyai daya tarik sedemikian rupa sehingga siswa yang kurang menguasai konsep merasa bimbang dan pada akhirnya mereka terkecoh untuk memilih pengecoh sebagai jawaban benar (Rahayu \& Djazari, 2016). Dari hasil penelitian, soal dengan kategori pengecoh yang kurang baik bahkan tidak baik terdapat 5 soal yaitu soal nomor 1, 9, 11, 13 dan 23. Kelima soal tersebut sebaiknya dirubah atau diberikan jawaban pada pilihan ganda yang lebih baik lagi.

Salah satu contoh soal dengan efektivitas pengecoh yang tidak baik pada SMA Pasundan 7 dan Pasundan 8 Bandung terdapat pada soal nomor 1 "Zacky merupakan seorang mahasiswa tingkat akhir ...." dengan pilihan jawaban "A. membayar uang semester, B.Membeli buku dan printer, C. Membeli buku dan membayar uang semester, D.Membayar uang semester dan membeli printer, E. Memenuhi semua kebutuhan dengan cara meminjam.". Dari soal dan pilihan jawaban yang disediakan butir soal nomor 1 merupakan soal dengan efektivitas pengecoh yang tidak baik karena siswa yang telah mengikuti proses pembelajaran dan memahami ataupun kurang memahami materi tersebut akan mudah menjawab dengan jawaban yang benar dan tidak terkecoh oleh pilihan jawaban yang lain. Kekurangannya mungkin hanya terletak pada rumusan kalimatnya sehingga perlu ditulis kembali dengan perubahan seperlunya yang lebih memerlukan pemikiran dalam menentukan jawaban.

Sedangkan contoh soal dengan efektivitas pengecoh yang baik di SMA Pasundan 7 dan Pasundan 8 Bandung terdapat pada soal nomor 6 "Diketahui fungsi permintaan Qd= 3P-8. Pada saat harga ...." Dengan pilihan jawaban A. (4;20),B. (20;4), C. (-4;20), D. (-20;4), E. $(-4 ;-20)$. Soal tersebut memiliki efektivitas pengecoh yang baik karena dalam menentukan jawaban yang benar siswa yang telah mengikuti proses pembelajaran perlu 
berfikir keras karena pilihan jawaban pengecoh yang disediakan memiliki daya tarik yang besar sehingga seolah-olah pilihan jawaban tersebut adalah jawaban yang benar .

\section{PENUTUP}

Berdasarkan hasil analisis data yang telah dilakukan dapat disimpulkan bahwa:

1. Kemampuan siswa dalam menjawab soal didapatkan hasi $85(32 \%)$ siswa yang mampu menjawab lebih dari setengah soal uji dengan benar, sedangakan sebanyak $182(68 \%)$ siswa belum mampu menjawab setengah soal uji dengan benar.

2. Hasil klasifikasi soal dalam ranah kognitif dari 28 soal didapatkan $\mathrm{C} 1$ (recognition) sejumlah 0 butitr soal (0\%),C2 (recognition) sejumlah 2 butir (7,14\%), C3 (application) sejumlah 8 butir soal (28,57\%), C4 (analysis) sejumlah 17 butir soal (60.71\%), C5 (synthesis) sejumlah $1(3,57 \%)$, dan C6 ( evaluation) sejumlah 0 butir soal $(0 \%)$.

3. Hasil indeks kesukaran soal didapatka bahwa soal yang tergolong sukar berjumlah 9 butir $(32,14 \%)$ yaitu butir soal nomor $6,8,12,14,17,18,20,24$ dan 26 . Soal dalam kategori sedang berjumlah 14 soal (50\%) yaitu butir soal nomor $3,4,5,7,10,11,15,16,19,21$, $22,25,27$ dan 28 . Soal dalam kategori mudah berjumlah 5 soal $(17,85 \%)$ yaitu soal nomor $1,2,9,13,2$ dan 3.

4. Hasil indeks daya pembeda soal didapatka bahwa butir soal tergolong negatif (tidak baik) berjumlah 2 butir $(7,4 \%)$ yaitu butir soal nomor 1 dan 26 . Soal dalam kategori jelek berjumlah 5 soal $(17,86 \%)$ yaitu nomor $1,7,17,19$ dan nomor 24 . Soal dalam kategori cukup berjumlah 11 soal $(39,29 \%)$ yaitu nomor $4,5,6,11,14,0,21,23,25$ dan 28 . Soal dalam kategori baik berjumah 9 soal $(32,14 \%)$ yaitu nomor $3,8,9,10,12,13,15,16$ dan 27. Soal dalam kategori baik sekali berjumlah 1 soal (3,57\%) yaitu soal nomor 2 .

5. Hasil efektivitas pengecoh soal didapatka bahwa soal dengan efektivitas pengecoh sangat baik berjumlah 8 soal $(28,57 \%)$ yaitu nomor $14,15,16,18,24,25,26$ dan 27 . Soal dalam kategori baik berjumlah 10 soal (35,71\%) yaitu nomor 4, 5, 6, 7, 8, 12, 19, 20, 21 dan 22. Soal dalam kategori cukup berjumlah 5 soal (17,85\%) yaitu nomor 2, 3, 10, 17 dan 28,. Sola dalam kategori kurang baik berjumlah 2 soal $(7,14 \%)$ yaitu nomor 11 dan 23 . Sedangkan soal dalam kategori tidak baik berjumlah 3 soal $(10,71 \%)$ yaitu 1, 9 dan 13.

\section{DAFTAR PUSTAKA}

Arends, R. I. (2001). Learning to teach (5th ed.). Boston: McGraw-Hill Comp. Inc.

Arikunto, S. (2016). Prosedur Penelitian: Suatu Pendekatan Praktik. Jakarta: Rineka Cipta.

B. Uno, H. (2013). Teori Motivasi dan Pengukurannya. Jakarta: Bumi Aksara.

Daryanto. (2010). Evaluasi Pendidikan. Jakarta: Rienaka Cipta.

Lyn, J., Ramos, S., Dolipas, B., \& Villamor, B. (2019). Higher Order Thinking Skills and Academic Performance in Physics of College Students: A Regression Analysis. International Journal of Innovative Interdisciplinary Research, 4, 48-60.

Purwanto. (2013). Evaluasi Hasil Belajar. Yogjakarta: Pustaka Pelajar.

Rahayu, R., \& Djazari, M. (2016). Analisis Kualitas Soal Pra Ujian Nasional Mata Pelajaran Ekonomi Akuntansi. Jurnal Pendidikan Akuntansi Indonesia, 14(1). https://doi.org/10.21831/jpai.v14i1.11370

Setiani, A., \& Donni, J. P. (2015). Manajemen Peserta Didik dan Model Pembelajaran. Bandung: Alfabeta.

Sudjana, N. (2014). Penilaian Hasil Proses Belajar Mengajar. Bandung: PT Remaja Rosdakarya.

Sugiyono. (2014). Metode Penelitian Pendidikan Pendekatan Kuantitatif, Kualitatif Dan R\&D. Bandung: Alfabeta.

Syah, M. (2014). Psikologi Pendidikan dengan Pendekatan Baru. Bandung: PT Remaja 
Rosda Karya.

Waseso, H. P. (2018). Kurikulum 2013 Dalam Prespektif Teori Pembelajaran Konstruktivisme. Ta'lim, 1(1), 59-72.

Widoyoko, E. P. (2016). Penilaian Hasil Pembelajaran di Sekolah. Yogyakarta: Pustaka Pelajar.

Yani, A., Asri, A. F., \& Burhan, A. (2014). Distraktor Soal Ujian Semester Ganjil Mata Pelajaran Produktif Di Smk Negeri 1 Indralaya Utara. Jurnal Pendidikan Teknik Mesin, 1(2), 98115. https://doi.org/https://doi.org/10.36706/jptm.v1i2.7410 